\title{
PRELIMINARY RESULTS OF ESTIMATING SOIL MOISTURE OVER BARE SOIL USING FULL-POLARIMETRIC ALOS-2 DATA
}

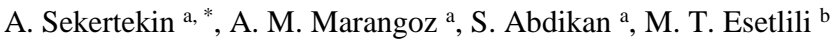 \\ a BEU, Engineering Faculty, Geomatics Engineering Department 67100 Zonguldak, Turkey - (aliihsan_sekertekin, \\ aycanmarangoz)@hotmail.com, sabdikan@beun.edu.tr

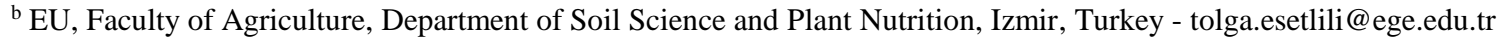

GeoAdvances 2016

KEY WORDS: Soil Moisture, Synthetic Aperture Radar (SAR), ALOS-2, Backscattering coefficient $\left(\sigma^{\circ}\right)$, Gravimetric Method

\begin{abstract}
:
Synthetic Aperture Radar (SAR) imaging system is one of the most effective way for Earth observation. The aim of this study is to present the preliminary results about estimating soil moisture using L-band Synthetic Aperture Radar (SAR) data. Full-polarimetric (HH, HV, VV, VH) ALOS-2 data, acquired on 22.04.2016 with the incidence angle of $30.4^{\circ}$, were used in the study. Simultaneously with the SAR acquisition, in-situ soil moisture samples over bare agricultural lands were collected and evaluated using gravimetric method. Backscattering coefficients for all polarizations were obtained and linear regression analysis was carried out with in situ moisture measurements. The best correlation coefficient was observed with VV polarization. Cross-polarized backscattering coefficients were not so sensitive to soil moisture content. In the study, it was observed that soil moisture maps can be retrieved with the accuracy about $14 \%$ (RMSE).
\end{abstract}

\section{INTRODUCTION}

Soil moisture is a key parameter for many environmental phenomena, especially for meteorological, agricultural and hydrological applications (Verhoest et al., 2008; Ahmad et al., 2011; Lakshmi, 2013). In addition, soil moisture information can be used as an indicator for natural disasters such as flooding and droughts, and for environmental changes, such as dust storms and erosions (Canada Center for Remote Sensing, 2008; Ahmad et al., 2011). Thus, monitoring spatial and temporal variations in soil moisture is of great importance for ecological balance. However, measuring accurate in situ soil moisture is expensive and time-consuming, also to observe temporal changes it requires repetitive measurements periodically.

Remote sensing is an effective technology to understand the behaviour of the world and to evaluate the changes on Earth. Moreover, remote sensing is a potential alternative way for estimating the distribution and quantity of soil moisture at a variety of scales, without expensive, time-consuming and tiring in situ measurements (Kornelsen \& Coulibaly, 2013). In recent years, radar remote sensing with different wavelengths is used to monitor spatial and temporal variations in soil moisture. Many studies have been presented to retrieve soil moisture content from X-band (Aubert et al., 2011; Baghdadi et al., 2011; Zribi et al., 2012; Kseneman et al., 2012; Baghdadi et al., 2012; Kweon et al., 2012; Satalino et al., 2012) and C-band (Gherboudj et al., 2011; Moran et al., 2011; Pasolli et al., 2011; Merzouki et al., 2011; Livens \& Verhoest, 2012; Jacome et al., 2013; Wang et al., 2013) SAR images; however, few studies were carried out using L-band (Paloscia et al., 2012; Balenzano et al., 2013) SAR data.

The only current operational high resolution L-band SAR satellite is ALOS-2 and the aim of this study is to investigate the effectiveness of new generation L-band satellite ALOS-2 images on estimating soil moisture content on bare soils.

\section{STUDY AREA AND MATERIAL}

An agricultural region in Bakircay river basin in Bergama was chosen as study area (Figure 1). Bergama is one of the districts of İzmir province. The study area is located on the northern side of the city Izmir. It is an agricultural region with different kinds of products including cotton, okra, corn, grape, tobacco and olive.

\footnotetext{
* Corresponding author
} 


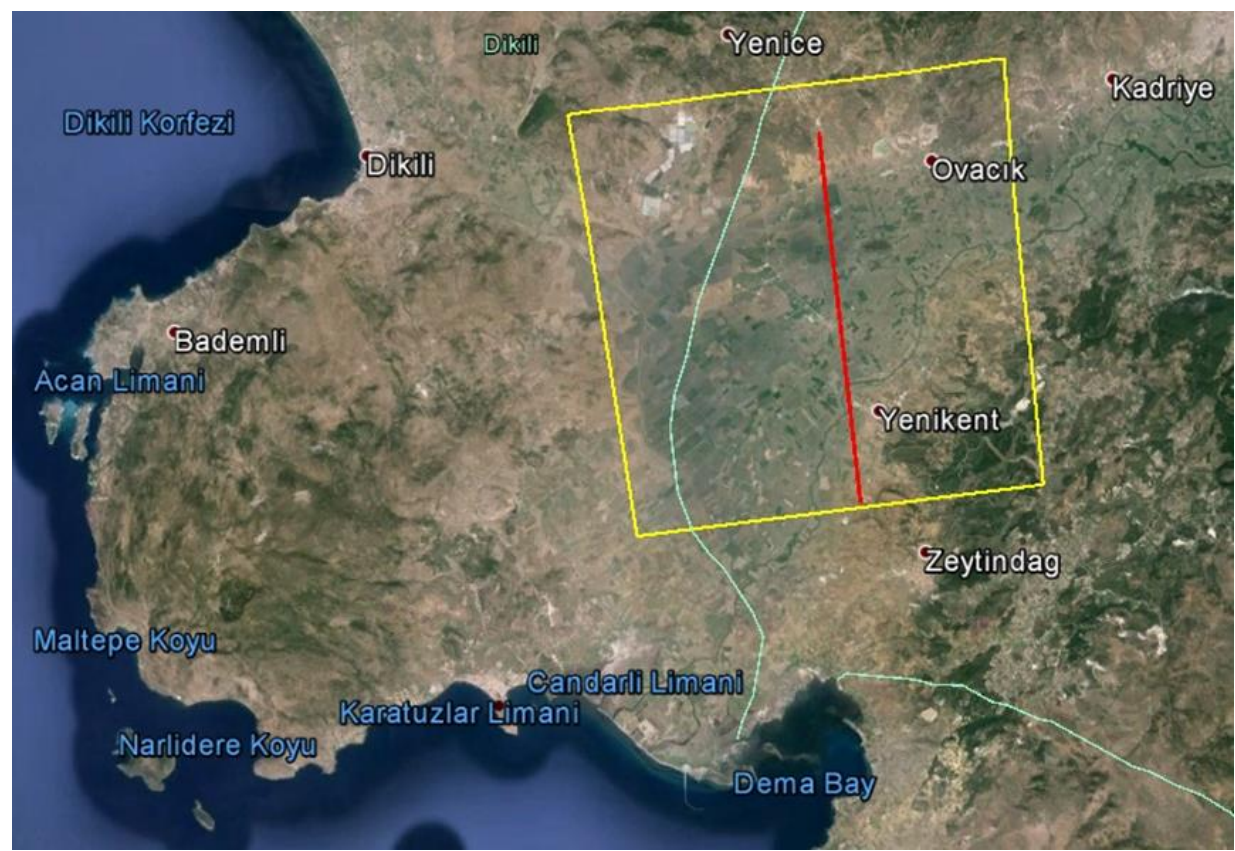

Figure 1. Boundary (yellow frame) of the study area from Google Earth images

In this research, full-polarimetric $(\mathrm{HH}, \mathrm{HV}, \mathrm{VV}, \mathrm{VH})$ ALOS-2 images, acquired on 22.04.2016 with the incidence angle of $30.4^{\circ}$, were utilized to obtain backscattering coefficient. ALOS2 satellite specifications are presented in Table 1. The images used in this study are acquired as strip map high sensitive mode with $5.1 \mathrm{~m}$ range and $4.3 \mathrm{~m}$ azimuth resolution.

\begin{tabular}{|c|c|c|}
\hline \multicolumn{2}{|l|}{ SENSOR } & SAR \\
\hline \multicolumn{2}{|c|}{ PALSAR-S (Frequency) } & L-band (1.2 GHz band) \\
\hline \multirow{3}{*}{$\begin{array}{l}\text { OBSERVATION } \\
\text { MODE }\end{array}$} & Spotlight & Resolution: 1x3m Swath:25 km \\
\hline & $\begin{array}{l}\text { Strip } \\
\text { Map }\end{array}$ & $\begin{array}{l}\text { Resolution: 3-10m Swath:50-70 } \\
\mathrm{km}\end{array}$ \\
\hline & ScanSAR & $\begin{array}{l}\text { Resolution: } 60-100 \mathrm{~m} \\
\text { Swath:350 km }\end{array}$ \\
\hline \multicolumn{2}{|l|}{ DESIGN LIFE } & 5 years (target: 7 years) \\
\hline \multicolumn{2}{|c|}{ SATELLITE MASS } & Approx. $2100 \mathrm{~kg}$ \\
\hline \multicolumn{2}{|c|}{$\begin{array}{l}\text { MISSION DATA } \\
\text { TRANSMISSION } \\
\end{array}$} & $\begin{array}{l}\text { Direct transmission, via data } \\
\text { relay satellite }\end{array}$ \\
\hline \multicolumn{2}{|c|}{ LAUNCH DATE } & 24 May 2014 \\
\hline \multicolumn{2}{|c|}{ LAUNCH VEHICLE } & H-IIA launch vehicle No.24 \\
\hline
\end{tabular}

Table 1. ALOS-2 Satellite specifications

\section{METHODOLOGY}

Simultaneously with ALOS-2 acquisition, in situ soil moisture measurements have been carried out over 41 bare agricultural fields. Only one sample was collected from each field. It represents whole field because the fields are not irrigated. After collecting samples, soil moisture content was determined for each field using gravimetric method.

The workflow diagram of the study is presented in Figure 2. Firstly, raw ALOS-2 data were geometrically corrected and then radiometric calibration (sigmanought conversion) for all polarizations was implemented. After the radiometric calibration, the images were subsetted so as to include the study area. For each agricultural site, mean linear backscattering coefficients were extracted by means of spatial analysis and each linear backscattering coefficient was converted to decibel
(dB). Finally, Backscattering coefficients in $\mathrm{dB}$ and gravimetric soil moisture content for each site were utilized in linear regression analyses.

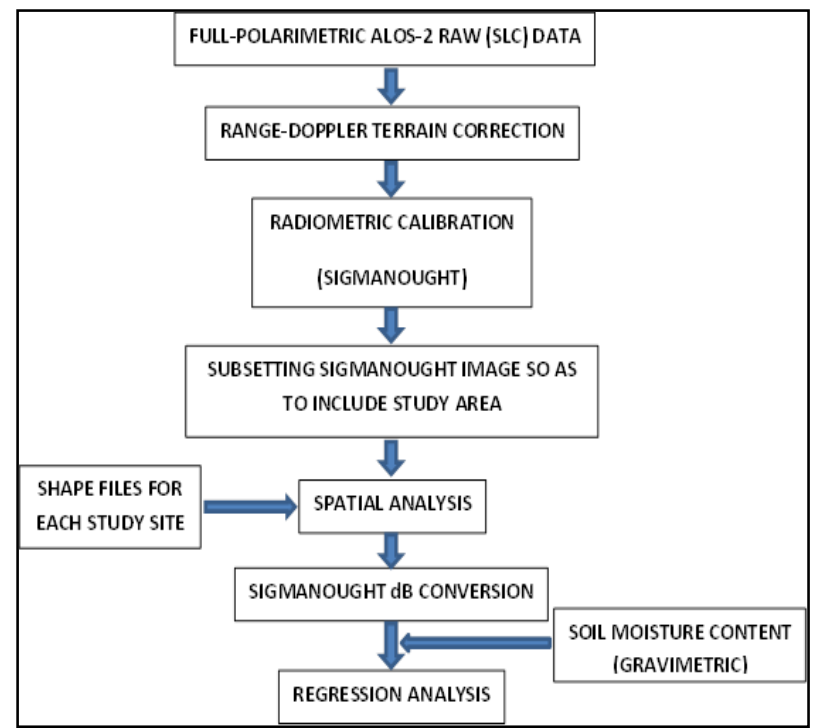

Figure 2. Workflow diagram of the study

\section{RESULTS}

The results of the linear regression analyses are presented in Figure 3. As it is clear from the Figure 3, backscattering coefficients in VV and $\mathrm{HH}$ polarization presents best results for our study sites. Cross-polarized backscattering coefficients are not so sensitive to soil moisture content as well as co-polarized backscattering coefficients. In addition, accuracy assessment in VV polarization was obtained 14\% RMSE. 


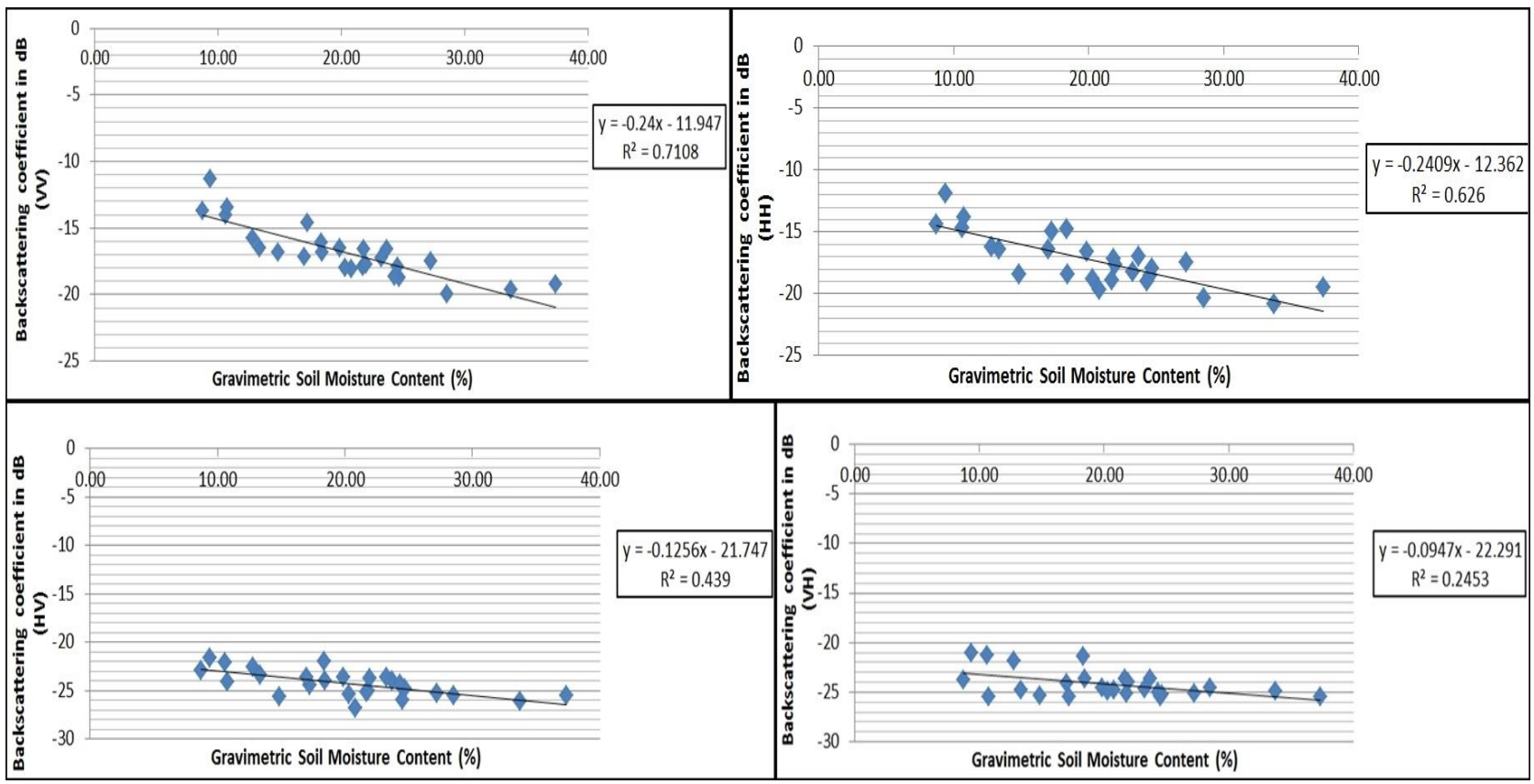

Figure 3. The results of the linear regression analyses

\section{CONCLUSION}

In this study, the potential of ALOS-2 data for estimating soil moisture content over bare agricultural fields was examined. For this purpose, Full-polarimetric data acquired on 22 April 2016 with the incidence angle $30.4^{\circ}$ were utilized and simultaneously with the SAR acquisition in situ soil moisture measurements were carried out using gravimetric method. Linear regression analysis was performed between backscattering coefficients of SAR images and ground soil moisture measurements. Obtained results showed that copolarized backscattering coefficient is more sensitive to soil moisture content than the cross-polarized backscattering coefficient over bare soils for our case study. It is clear from this research that L-band SAR images have potential for soil moisture mapping on a large scale. As a future work, another surface parameter surface roughness will be included to the study and it will be investigated how it has influence on estimating soil moisture with SAR data.

\section{ACKNOWLEDGEMENTS}

Full-polarimetric ALOS-2 satellite images have been provided by Bulent Ecevit University scientific research project: 201547912266-04.

\section{REFERENCES}

Ahmad, A., Zhang, Y., \& Nichols, S., 2011. Review and evaluation of remote sensing methods for soil-moisture estimation. SPIE Reviews, 2, 028001.

Aubert, M., Baghdadi, N., Zribi, M., Douaoui, A., Loumagne, C., Baup, F., El Hajj, M., Garrigues, S., 2011. Analysis of TerraSAR-X data sensitivity to bare soil moisture, roughness, composition and soil crust. Remote Sensing of Environment, 115(8), pp. 1801-1810.

Baghdadi, N., Camus, P., Beaugendre, N., Issa, O.M., Zribi, M., Desprats, J.F., Rajot, J.L., Abdallah, C., Sannier, C., 2011. Estimating Surface Soil Moisture from TerraSAR-X Data over
Two Small Catchments in the Sahelian Part of Western Niger. Remote Sens., 3, pp. 1266-1283.

Baghdadi, N., Aubert, M., Zribi, M., 2012. Use of TerraSAR-X Data to Retrieve Soil Moisture Over Bare Soil Agricultural Fields. IEEE GEOSCIENCE AND REMOTE SENSING LETTERS, 9(3).

Balenzano, A., Satalino, G., Lovergine, F., Rinaldi, M., Iacobellis, V., Mastronardi, N., Mattia, F., 2013. On the use of temporal series of L- and X-band SAR data for soil moisture retrieval. Capitanata plain case study. European Journal of Remote Sensing, 46, pp. 721-737.

Canada Center for Remote Sensing, 2008. "Fundamentals of remote sensing applications", http://www.ccrs.nrcan.gc.ca/resource/tutor/fundam/chapter5/14 _e.php (May 2016).

Gherboudj, I., Magagi, R., Berg, A.A., Toth, B., 2011. Soil moisture retrieval over agricultural fields from multi-polarized and multi-angular RADARSAT-2 SAR data. Remote Sensing of Environment, 115(1), pp. 33-43.

Jacome, A., Bernier, M., Chokmani, K., Gauthier, Y., Poulin, J., De Sève, D., 2013. Monitoring Volumetric Surface Soil Moisture Content at the La Grande Basin Boreal Wetland by Radar Multi Polarization Data. Remote Sens., 5, pp. 4919-4941.

Kornelsen, K. C., Coulibaly, P., 2013. Advances in soil moisture retrieval from synthetic aperture radar and hydrological applications. Journal of Hydrology, 476, pp. 460489 ,

Kseneman, M., Gleich, D., Potočnik, B., 2012. Soil-moisture estimation from TerraSAR-X data using neural networks. Machine Vision and Applications, 23, pp. 937-952.

Kweon, S., Hwang, J., Oh, Y., 2012. COSMO SKYMED AO PROJECTS -SOIL MOISTURE DETECTION FOR VEGETATION FIELDS BASED ON A MODIFIED WATER- 
CLOUD MODEL USING COSMO-SKYMED SAR DATA. IGARSS 2012, Munich, Germany, pp. 1204 - 1207.

Lakshmi, V., 2013. Remote Sensing of Soil Moisture. ISRN Soil Science, 2013, Article ID 424178, 33 pages.

Lievens, H., Verhoest, N.E.C., 2012. Spatial and temporal soil moisture estimation from RADARSAT-2 imagery over Flevoland, The Netherlands, Journal of Hydrology, 456-457, pp. 44-56.

Merzouki, A., McNairn, H., Pacheco, A., 2011. Mapping Soil Moisture Using RADARSAT-2 Data and Local Autocorrelation Statistics. IEEE JOURNAL OF SELECTED TOPICS IN APPLIED EARTH OBSERVATIONS AND REMOTE SENSING, 4(1), pp. 128-137.

Moran, M.S., Alonso, L., Moreno, J.F., Mateo, M.P.C., Fernando de la Cruz, D., Montoro, A., 2012. A RADARSAT-2 Quad-Polarized Time Series for Monitoring Crop and Soil Conditions in Barrax, Spain. IEEE Transactions on Geoscience and Remote Sensing, 50(4), pp. $1057-1070$.

Paloscia, S., Pettinato, S., Santi, E., 2012. Combining L and X band SAR data for estimating biomass and soil moisture of agricultural fields. European Journal of Remote Sensing, 45, pp. 99-109.

Pasolli, L., Notarnicola, C., Bruzzone, L., 2011. Estimation of Soil Moisture in an Alpine Catchment with RADARSAT2 Images. Applied and Environmental Soil Science, 2011, Article ID 175473,12 pages.

Satalino, G., Panciera, R., Balenzano, A., Mattia, F., Walker, J., 2012. COSMO-SKYMED MULTI-TEMPORAL DATA FOR LANDCOVER CLASSIFICATION AND SOIL MOISTURE RETRIEVAL OVER AN AGRICULTURAL SITE IN SOUTHERN AUSTRALIA. IGARSS 2012, Munich, Germany, pp. $1204-1207$.

Verhoest, N. E. C., Lievens, H., Wagner, W., A' lvarez-Mozos, J., Moran, M. S., Mattia, F., 2008. On the soil roughness parameterization problem in soil moisture retrieval of bare surfaces from synthetic aperture radar. Sens. J., 8, pp. 42134248 .

Wang, H., Allain, S., Meric, S., Pottier, E., 2013. SOIL MOISTURE CHARACTERIZATION USING MULTIANGULAR POLARIMETRIC RADARSAT-2 DATASETS. ESA Living Planet Symposium, Edimburgh, United Kingdom, pp. 1-4.

Zribi, M., Kotti, F., Lili-Chabaane, Z., Baghdadi, N., Ben Issa, N., 2012. Soil texture estimation over a semiarid area using TerraSAR-X radar data. IEEE Geoscience and Remote Sensing Letterss, 9(3), pp.353-357. 